\title{
Social Media as a Tool for Political Resistance: Lessons from the Arab Spring and the Nigerian Protests
}

\section{Emmanuel Ufuophu-Biri, PhD}

Senior Lecturer and Head of Department, Mass Communication, Delta State University, Abraka, Nigeria

\section{Lucky Ojoboh, PhD}

Lecturer, Mass Communication, Delta State University, Abraka, Nigeria

Doi:10.5901/ajis.2017.v6n1p61

\section{Abstract}

The popular revolutions that swept across North Africa and the Middle East (NAME) countries, popularly called the "Arab Spring", removed several sit-tight regimes and threatened to remove some others. Until those revolutions, nobody in the region had the audacity to question the actions of the governments. The mass media in the region had no freedom of operation and could not be used to express opinions or ideas that contradicted government wish or stand. However, the self-immolation of Tarek al-Tayeb Mohamed Bouazizi on 17 December, 2010 in Tunisia and his subsequent death led to an unstoppable torrent of protests across the region. The social media became the tool of communication, organization and coordination during the protests. The social media thus provided the protesters with an alternative voice of expression, which they used to mobilize and organize the protests. This study therefore, examined the role of the social media in the the Arab Spring. The study which is theoretical concludes that the use of the social media was very effective in success of the revolution. The study showed that without the social media, the revolution might not have been successful or might not have taken place at all. The study thus recommends that people should continue to use the social media to protest against oppressive regimes and all forms of oppression.

Keywords: Arab Spring, Social Media, Mainstream media, Revolution, North Africa and Middle East

\section{Background}

The social media are basically Internet social networking sites that connect people together for different purposes. The social media came on board in 1995 with the establishment of Asian Avenue and Classroom.com as social networks. Social media became very popular following the establishment of Facebook in 2004.

Social media connects community of friends together (Ufuophu-Biri, 2013). They are intended to facilitate easier, cheaper and faster communication and relationship. They bring together people in different continents. The participants become virtual friends and actually behave and act as if they are physically present (Joinson, 2008). Members of social media community do not necessarily have to travel across spatial distance to meet themselves. By connecting to the Internet, they kill the distance and they meet and discuss virtually thus according to Caincross (2001), distance is killed in the process.

The social media are used for different purposes including friendship, business, education, advertising, politics and expression of dissent voices, mass mobilization and journalism. However, unlike the conventional media, there are no control, no code of ethics and no gate-keeping (Belicove, 2012).

The use of the social media has also caused revolutions in some parts of the world as witnessed in the Arab Spring, Occupy Wall Street, Occupy London and Occupy Nigeria and the Iranian post-election result (Yousef, 2012). The 
Arab Spring revolutions It started in Tunisia with the self-immolation of a graduate street vendor, Tarek al-Tayeb Mohamed Bouazizi on 17 December, 2010. He was angry when a municipal official and her aides confiscated his wares and the harassment and humiliation they inflicted on him. Feeling frustrated, he set fire on himself and subsequently died in a hospital. The general populace became infuriated.

The then Tunisian President, Zine El Abidine Ben Ali visited him in the hospital before he died. The president's visit did not assuage the citizens' anger and the consequence was a nationwide uprising that caused President Ben Ali to abdicate his position and run into exile in Saudi Arabia on 14 January 2011, after 23 years in power (Belicove, 2012).

The uprising, according to Yousef (2012), spread almost immediately to Egypt, Libya, Saudi Arabia, Bahrain, Yemen and Syria. Social media sites, principally Facebook, Twitter and Youtube were used significantly to organize the protests that wiped out the sit-tight regimes of Ben Ali, Ghadafi and Hosni Mubarak.

Srinivasan (2012) writes that the protesters could not use mainstream media, especially the broadcast media and, since the protesters were widely dispersed across different places, they would have had no other effective means of communication and coordination during the uprising if the option of the social media was not available. Corroborating the above point, DeLong-Bas (2012) explains that the social media played an important role in the revolutions by bringing the people together and helping in the coordination of the massive revolutions in Libya, Egypt, Tunisia, Yemen and Syria. It thus became a powerful instrument for political protest.

\section{Methodology}

The study aims at interrogating the role of the social media in the Arab and Middle East revolutions of 2011 and the Nigerian mass protests and uprising of early 2012 over the removal of petroleum subsidy. The study also aims at determining how the social media are used in the organization and coordination of mass protests.

The study adopted the review/historical method whereby information was extracted from existing works and records. The study reviewed intensively works that had been done on subject and draws inferences from the general findings of the works reviewed. The existing information was reviewed thematically to arrive at the conclusion drawn in this study.

\section{Social Media and the Arab Spring Revolutions}

Until December, 2010, when protests began in Tunisia, the social media had been used mainly for the establishment, maintenance and sustenance of social relationship and other forms of social communication and citizen journalism. However, Dedanne (2009), Leach (2009), Picard (2009), Russell (2012) Fisher (2012) explains separately that social media deviated from their traditional role of social communication and relationship and engaged in revolutionary function when they were used for the Arab Spring revolutions. They point out further that most of those countries, where the revolutions took place, had despotic governments through which the citizens' fundamental human rights were abused. The Arab Spring uprisings of 2011 however made the social media to be celebrated as effective tools for political discourse and democracy building.

Aday, Farrell, Lynch, Sides, and Freelon (2012) note that ordinary citizens, including journalists were prohibited from criticizing governments in virtually all the affected countries in the NAME revolutions but the governments of the affected countries could not prevent the masses from using the social media to organize and execute the revolutions. For instance, in Egypt, there was a special Facebook page called We are all Khaled Said, which was considered to be the cornerstone of the Egyptian revolution. It was created by Wael Ghonim, the marketing officer for Google in the Middle East, in honour of Khaled Said, who was murdered by police in Alexandria about six months before the revolution began in January of 2011. Yousef (2012) adds that popular social media platforms, includingTwitter and Facebook, were used significantly to organize and coordinate the revolutions. The revolutions brought down the regimes in Tunisia, Egypt and Libya and caused bloody uprisings in Bahrain, Syria, and Yemen.

Social Capital (2012) explains that these revolutions relied on social media for effective organization, mobilization and coordination. Citizens were able to take photographs and videos of the atrocities of Syrian President Bashar AlAssad's crackdown on the protesters and uploaded these images to Facebook or YouTube, fanning international pressure on Assad to soft pedal. Reporters Without Border (2011) submits that the regime of Muammar Gaddafi had no iota of tolerance for dissent. The mass media in Libya during the regime of Gaddafi were more of instrument of the regime, something akin to the communist/socialist press system but the citizen used the social media successfully in the revolution against him. 
No mass media organization had the courage to publish or broadcast what could be regarded as opposing the interest of the regime. A similar situation existed in Egypt, Tunisia, Yemen, Bahrain, Syria and Iran. It was suicidal for the mass media or an individual to pose as a dissenting voice in any of the countries. However, the use of the social media surprisingly destroyed the myth and reality of non-opposition in the affected countries. Contrarily and unexpectedly, as Kassim (2012) explains, the social media, being capable of sharing an immense amount of uncensored and accurate information, empowered the masses to overthrow several dictators during the Arab Spring revolutions. Kassim (2012) stresses that in places such as Egypt, Tunisia, and Yemen; uprising action plans such as protests made up of thousands of people were organized through social media platforms. The protesters used Facebook to schedule the protests and Twitter to coordinate, and YouTube to tell the world. Kassim points out social networks have thus broken the psychological barrier of fear by helping many people to connect and share information.

Before the revolution in Tunisia, none of the affected countries' citizens would had dared to use the social media against government, but the success of the Tunisian revolution gave citizens of the other affected countries the impetus to use the social media as weapons of opposition (Reporters Without Border, 2012). The use of the social media was aided by the availability and application of modern communication gadgets such as smart phones, tablets and portable laptop. According Taylor (2012), government could not sanction or block the use of the social media. Large rallies were organized and coordinated through the social media without the people meeting in a particular location before they could be communicated to, thus killing distance and physical presence. Additionally, through the social media, people outside the affected countries got the full information about the revolution.

According to O'Donnell (2012)) big media houses, such as CNN, Aljazeera, New York Times, also relied largely on reports from the social media. Noueihed and Warren (2012) assert that the social media forced the traditional media to re-evaluate their role and weakened the power of the national governments and hierarchal organizations in the affected Arab Spring Revolutions.

As the Arab Spring spread, governments began to realize the potency of the social media. President Hosni Mubarak of Egypt tried to limit the nation's access to the Internet during the eighteen days protest from late-January to early-February 2011 because the government could no longer control the flow of information to the citizens, or the outside world.

In Egypt, the social media became very effective in the organization of anti-government rallies in Tahrir Square, Cairo, Alexandria and other cities. While government media houses were reeling disinformation and propaganda, the social media which could not be censored was reeling out the true situation and sensitizing the citizens to participate actively in the revolution (Reardon, 2012). Finally, the people defeated President Mubarak as he stepped down and was arrested and charged for various offences committed against the people during the revolution. Without the social media, the NAME revolution would have been a total failure. Reardon based his argument on the information passage and coordination role the social media played during the revolutions.

For instance, in Libya, Egypt and the other countries, the people could not access the mainstream media for their personal views which were not in consonance with government's will. But the social media provided a potent alternative (Tavanam, 2012, O'Donnell, 2012). For instance, during the week before Egyptian President, Hosni Mubarak's resignation the total rate of tweets from Egypt and other countries about the political protest in Egypt increased from 2,300 a day to 230,000 a day (O'Donnell, 2012)

Carvin (2012) suggests that without the social media, information dissemination, organization and coordination during the revolutions in NAME would have been difficult.

For instance, Gaddafi used the state mass media to counter the information which emanated from the social media, but the social media overwhelmed the state media. Thus Reardon (2012) asserts that from Benghazi to Tripoli, protesters were effectively mobilized through the social media.

What the military or opposition could not do to Gaddafi in his 42 years regime was effectuated with the aid of the social media. Gaddafi was captured and summarily executed in Sirte on October 20, 2011. In Syria, the revolution has lasted up till this moment. What started in early 2011 through mass rallies coordinated through the use of the social media against the President Assad regime has blossomed into a full-fledged civil war. Eltantawy and Wiest (2012) write that the protesters did not have access to or operate mainstream media, but they took full advantage of the social media in information dissemination and coordination of the revolutions.

Many of the video broadcast by the big media organizations such as CNN, Aljazeera, EuroNews, CCTVN were footages from YouTube posted by amateur video men. For instance, the Assad government does not allow foreign media men into his held areas; even the few times they were allowed, they were guided and fed with disinformation and propaganda. Thus the social media became the veritable windows into the true happenings in Syria. 
Raddatz (2012) notes that before the successful revolution in NAME, Iranians had used the social media to organize protests against the disputed election that returned President Mahmoud Ahmadinejad. With the opposition driven underground and the press heavily censored, the Iranians resorted to the use of the social media. Foreign journalists were denied entry into the country. Only government media houses and loyal independent media organizations were allowed to operate. The people had no other alternative than to rely on the social media. The social media can therefore be adjudged to have played a significant role in the success of the Arab Spring Revolutions.

\section{Social Media and Nigerian Tropical Harmattan Mini Revolution of 2012}

In Nigeria, the social media also played a crucial role in the Nigerian Tropical Harmattan mini revolution against the government of President Goodluck Jonathan in January, 2012 following the increase in prices of petroleum products. Though the Nigerian independent mass media reported the protests, the social media played a significant role in organizing and sensitizing the masses. The mini revolution cut across major Nigerian cities such as Lagos, Abuja, Kano, Ibadan, Kaduna and Benin. Ogunlesi (2012) writes that the fuel price increase and the associated increase in the prices of commodities sparked off the nationwide Occupy facilitated by the use of the social media.

Millions of Nigerians used the social media to report stories, share opinions and persuade others to participate in the protests. People who ordinarily could not have had access to the mainstream media found a perfect alternative in the social media. While government broadcast stations such as NTA, FRCN and the state governments owned broadcast stations reeled out information from the government perspective, the social media aided the protesters and other supporters to get the true situation of things as well as comment freely.

Unlike in past protests where half truths were dished out to the public, in the January Nigerian Tropical Harmattan mini revolution, the whole truth was told because with the presence of the social media, there was no hiding place and no censorship. The mainstream media even made provision for the citizens to report directly to the mainstream media through the social media (Carvin, 2012).

Olua (2012) notes that the January 2012 protests were some of the most massive and successful mass movements in the history of Nigeria and that the use of the social media frustrated government's effort to restrict free flow of information on the protests and the state of affairs in the country.

Olua (2012) states further that Twitter featured numerous tweets and retweets regarding the protests, registered with rash tags such as Occupy Nigeria, Fuel subsidy is evil and Save Nigeria among others. Olofinlua (2012) holds a similar view and explains that the social media played significant roles in the Occupy Nigeria protests by raising consciousness among the people.

\section{How the Social Media Work in Mass Protest}

The social media have no geographical boundary, thus bringing to fruition the prediction of Gibson (1984). Gibson in his master peace, Neuromancer predicts a situation where there shall be no geographical boundaries for the mass media and information flow because of technological advancement. This is also in consonance with Marshall McLuhan's concept of Global Village in which he predicts that the evolving mass media technology shall reduce the entire world to a global village. As with a village, what happens in one part of the world would be known globally instantly and simultaneously. Any such occurrence shall also have a global impact.

The social media thus work in a way that once a connected user makes a post, his friends receive the post instantly and the friends of the friends connected to the third level, fourth level, and fifth level and beyond receive the post. Some of the recipients may repost the information. Before long, the information reaches millions of people both within and outside the national boundaries.

The social media thus enable the information to snowball and facilitate wider reception. Eltantawy and Wiest (2012) explain that in this process of information transfer, the mainstream media sometimes obtain stories from the social media. As a result of the spread and non-location specifics, the users of the social media can easily post what ordinarily they could not have posted. The people can therefore plan a protest on the social media without government obstructing their meeting places during the planning. Such meetings and planning do not require physical presence thus, distance and physical presence were killed (Srinivasan, 2012). Planners may assume anonymity in order to avoid security risk.

Since there is no specific location for the planning, government thus have difficulty in tracking down protesters during the planning process. People could do the planning with their phone handsets, tablets and laptops within the confine and comforts of their bedroom, cars, offices, buses, trains, or even on top of motor bikes without the physical 
presence of the other planners.

Aday, et al (2012) write that even during the actual protests, the protesters still dish out and receive information on the next line of action without resorting to the use of only public address system. Another plausible feature of the social media during protest is that protesters can sensitize themselves by using words and statements which ordinarily would have attracted the invocation of the law of sedition. In the case, government may not be able to track down such communicators because of the factor of anonymity.

The power of anonymity, death of distance, instantaneity and simultaneity of the social media help in the organization of protests against governments and establishments.

\section{Role of the Social Media in the Organization and Coordination of Protests}

Noueihed and Warren (2012) explain that the social media have far reaching advantages over the mainstream media in the coordination of mass actions. The social media, unlike the mainstream media, do not need any form of authorization or permission to operate.

The mainstream media are largely corporate organizations with some forms of registration by government or authorization by the government. Government could at will withdraw such authorization or permission to operate. As a result, the mainstream media tread with care. The social media are not bound by any of the strings that bind the mainstream media. The rule of engagement for the social media is largely "there is no rule".

These unique characteristics, according to Kassim (2012), which some observers regard as short comings of the social media, have turned out to be the Achilles heel of many governments. Since governments have no hold on the social media, coupled with the easy accessibility and availability of the social media, protesters are able to plug into the resources of the social media and use them successfully to organize and coordinate mass protests against governments.

\section{The Way Forward for Social Media and Mass Protests}

Taylor (2012) predicts that the last might not have been heard about using the social media to organize mass protests against governments and establishments. Carvin (2012), points out that the different protests in which the social media have played significant roles have been regarded as legitimate protests against despotic regimes such as in Libya, Egypt, Tunisia, Iran, Syria and Yemen. He thus argues that social media have become a weapon against oppression thus many non-democratic governments such as those of Iran, North Korea and China, Saudi Arabia make efforts to curtail the social media. He thus suggests that oppressed people and other concerned people deprived of access to a balance mainstream media system should use the social media to air their views, report themselves and protest against any illegality and oppression.

Noueihed and Warren (2012) explain that oppression from despotic governments may decline graduation by learning from the role of the social media in the 2011 Arab spring. They suggest that people should continue to use the social media as effective tools against oppression. Similarly, Yousef (2012) predicts that with the growing number of social media network sites, the social media have come to stay; and, from their role in the NAME revolution, they will continue to play important roles in future mass protests.

\section{Conclusion}

Conclusion could be drawn that the social media are potent tools in mass protests and revolutions against oppressive governments and establishments. Good examples were the Arab Spring revolutions of 2011. The review also indicated that the social media provide alternative voice to the masses in countries and systems where the mainstream media are biased or heavily censored.

Additionally, the social media use their unique characteristics, which tend to contradict conventional journalism ethics, to ensure successful organization and coordination of mass protests. With the success of the various mass protests in which the social media have played a significant role, there is the hope that the social media will continue to be relevant in mass protests and movements against oppressive regimes.

\section{Recommendations}

A people oppressed by their government should avail themselves the opportunity of using the social media to organize 
protests against such oppression; the citizens of countries with sit-tight regimes could resort to the use of the social media to fight for the entrenchment of democracy; people who are denied access to the mainstream media by their government should resort to the use of the social media as a viable alternative; and governments should be open to their citizens and listen to them to avoid the citizens resorting to the organization of massive protests through the social media.

\section{References}

Aday, S, Farrell, H, Lynch, M, Sides, J and Freelon, D. (2012). Blogs and bullets II: New media and conflict after the Arab Spring. (Online) Available: http://www.usip.org/publications. (August 22, 2012)

Belicove, M. (2012). Why social media may weaken the moral fiber of your workplace. (Online) Available: http://www.entrepreneur.com/ blog. (November 11, 2012)

Caincross, F. (2001). The Death of Distance: How the Communications Revolution is changing our lives. London: Texere Publishing Limited.

Carvin, A. (2012). Social Media, the Arab Spring and a Journalism Revolution. New York: Cuny Books

Dedanne, S.J. (2009). The Social media in the Mass media. A paper presented at a seminar in University of South Florida, St. Petersburg.

DeLong-Bas, N.J. (2012). The new social media and the Arab Spring. (Online) Available: http://www.oxfordislamicstudies.com/Public/ focus/essay0611_social_media.html. (December 22, 2012)

Eltantawy, N and Wiest, J.B. (2011). The Arab Spring, social media in the Egyptian Revolution: reconsidering resource mobilization theory. International Journal of Communication. 5, 33-42

Fisher, M. (2012). How the middle east uses social media, in four charts. (Online) Available: http://www.washingtonpost.com/blogs/ worldviews/wp/. (December 22, 2012)

Gibson, W. (1984). Neuromancer. Washington DC: Ace Books.

Joinson, A. N. (2008). Looking at', 'looking up' or 'keeping up with' people? motives and uses of Facebook. CHI 2008 Proceedings: 1027-1036.

Kassim, S (2012). Twitter revolution: how the Arab Spring was helped by social media. (Online). Available: http://www.policymic.com/ articles/10642. (August 22, 2012)

Leach, J. (2009). Creating Ethical bridges from journalism to digital news. (Online) Available: http:/.www.niemam.harvard.edu/ reportsitem.aspen. (September 10, 2009)

Noueihed, L and Warren, A.(2012). The Battle for the Arab Spring: Revolution, Counter-Revolution and the Making of a New Era. New Haven: Yale University Press.

O'Donnell, C. (2012). New study quantifies use of social media in Arab Spring. (Online) Available: http://www.washington.edu/news. (October 4, 2014)

Ogunlesi,T. (2012). The fuel subsidy crisis has woken Nigerians up. (Online) Available: http://www.guardian.co.uk/commentisfree. (June 14, 2014)

Olofinlua,T. (2012). nigerians wield social media during fuel subsidy protests. (Online) Available: http://www.dailykos.com/story. (June 8, 2015)

Olua, C. (2012). Social media drives the Occupy Nigeria protest in Nigeria and across the world. (Online) Available: http://www.ebusinessjournals.com. (October 4, 2015)

PewResearch. (2012). Social networking popular across globe: (survey report. http://www.pewglobal.org. (December 14, 2015)

Picard, R. (2009). Blogs Tweets Social Media, and the News Business. (Online) Available: http:/l.www.niemam.harvard.edu/ reportsitem.aspen. (December 14, 2015)

Raddatz,M. (2011). Social media aid Iran, Bahrain, Yemen protests. (Online) Available: http://www.abcnews.go.com. (October 4, 2015)

Reardon,S. (2012). Was the Arab Spring really a Facebook revolution? (Online) Available: http://www.newscientist.com/article/mg 21428596.400. (June 8, 2015)

Reporters Without Border (2011). Predator of Press Freedom: Libya-Muammar Gaddafi. New York: UNHCR

Russell, J. (2012). Report: Half of people that use social networks do so from mobile, Asia leads the way. (Online) Available: http://thenextweb.com/author/jonrussell. (December 14, 2015)

Social Capital.(2012). Twitter, Facebook and YouTube's role in Arab Spring/ Middle East uprisings. (Online) Available: http://socialcapital.wordpress.com. (December 13, 2015)

Srinivasan, R. (2012).Taking power through technology in the Arab Spring (Online) Available: http://www.aljazeera.com/indepth/opinion. (December 12, 2015)

Tavana,D.(2012). Social Media and the Arab Spring. (Online) Available: http://muftah.org/social. (December 13, 2015)

Taylor, K. (2012). Arab Spring really was social media revolution. (Online) Available: http://www.tgdaily.com/software-features/58426. (December 13, 2015)

Yousef, G. E. (2012). Social media giants leap into Arab World. (Online) Available: http://www.cnbc.com/id/49690234. (December 12, 2015) 